\title{
Polish Lowland Sheepdog
}

National Cancer Institute

\section{Source}

National Cancer Institute. Polish Lowland Sheepdog. NCI Thesaurus. Code C54054.

The Polish Lowland Sheepdog is medium-sized, strong and muscular, with

characteristically long, hanging hair that covers the eyes. The profuse hair on the

forehead, cheeks and chin make the head look bigger than it actually is. It is doubled-

coated and the body is covered with a long, dense, shaggy, thick coat that is reasonably

straight. The undercoat is soft and dense. Ears are heart-shaped, drop, and set

moderately high. Height: 17-20 inches. 